\title{
Social Support Affect Nurses' Job Satisfaction: A Literature Review
}

\author{
Istichomah Istichomah*(iD, I. Putu Juni Andika, Hillary V. E. Pesirahu \\ Department of Nursing, Sekolah Tinggi Ilmu Kesehatan Yogyakarta, Yogyakarta 55162, Indonesia
}

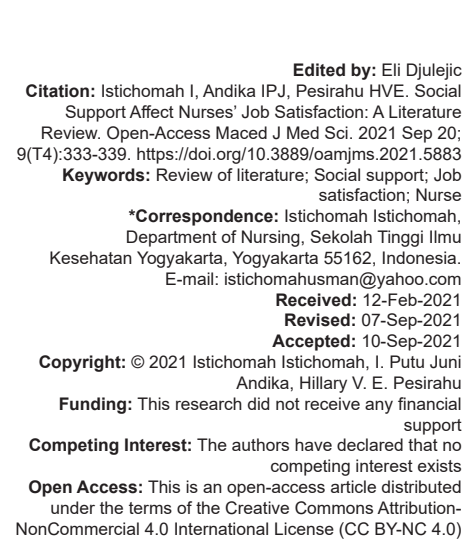

Abstract

BACKGROUND: Social support is an important predictor in improving job satisfaction. Nursing work satisfaction, in general, has a direct relationship with the positive impact on the quality of nursing services. Nurses who have good job satisfaction will produce good and optimal work performance that can create patient satisfaction. Results survey expressed the nurse lacks good support and the satisfaction of the felt work of the nurse is at a low level.

AIM: This study aims to review the nursing works of literature about relation to social support and identify the factors that may impact on job satisfaction among nurses.

METHODS: This literature uses inclusion and exclusion criteria, articles obtained, reviewed, and obtained from databases, namely, Google Scholar (2015-2020), PubMed (2015-2020), and Wiley Online Library (2015-2020). The search strategy with terms used in English is as follows: Social support and nurses' and job satisfaction. The year the literary source is taken from 2015 until 2020. Search strategy with the keyword "social support and nurse or job satisfaction," and in Bahasa Indonesia "dukungan sosial dengan kepuasan kerja perawat." This is to make sure all the articles obtained are relevant and appropriate, then the full text is downloaded and saved.

RESULTS: Initial identification of titles and abstracts is PubMed obtained 418,738 articles, at Wiley Online Library acquired 34,229 whereas on Google Scholar acquired 4400 articles so total obtained 457,367 articles. Review Literature results from 10 articles stating that social support is significantly and positively influential with nursing work satisfaction, social support to moderate work satisfaction against psychological pressure, as well as social support and job satisfaction affecting the desire of nurses to not abandon their work (turnover).

CONCLUSION: Social support can affect the jobs satisfaction of nurses, unresolved dissatisfaction can reduce the quality of nursing services and will have an impact on increasing the mortality rate.

\section{Introduction}

The nurse is a very reliable work to help and serve others or clients. Nurse also has the hope of being able to perform their duties and roles well to provide good service and achieve the optimal degree of health [1]. To create a good quality of work for nurses, nurses need social support from everyone around them [2].

Social support is a resource that helps when a person is depressed, social support can positively influence the health and well-being of individuals coming from family, friends, and work environment from both superiors and coworkers [3]. However, based on the results of the data from the European Working Condition Survey conducted in 2015-2018 by 32 countries in Europe, it showed that many workers have less social support from the employer at $45.04 \%$ and from colleagues at $49.35 \%$. The problem of social support is important because it provides great benefits for nurses and hospitals, if nurse gets good social support, it will impact on mental and physical nurses so that nurses can provide quality health-care services [3].

Every effort to improve the optimal health services should also be accompanied by improving the quality of nursing [4]. One of the causes of low-quality work for nurses is triggered by job satisfaction, satisfied nurses will be more productive than the unsatisfied nurse so that it will impact the quality of service provided [5]. Survey results by Monthly Index of Medical Specialities (MIMS, 2016) nurses often feel dissatisfied about their work, lazy to work, and having the desire to quit work one of the factors is less respectful than both colleagues and supervision and patients so that the nurse feels unappreciated for his work.

In a hospital, nursing is a health workforce that has the most interaction and meeting times with patients [6]. Nurses accompany and monitor the patient's health and provide comprehensive and professional nursing care so that the benchmark and determination, the quality in health services is nursing, nursing service is one of the measurement standards that affect the health service given to the hospital and vice versa [7]. The low level of nursing work satisfaction will lead to decreased performance, less optimal service, and loyalty to the organization also to the nursing profession to be decreased. Shekelle [8] explained that the low satisfaction of the work felt by the nurse will result in less optimal service resulting in an increasing in the death ratio of patients in hospital after hospitalized in 
the living room. Another impact that will be perceived is declining hospital imagery that could result in losses to hospital management organizations due to customer dissatisfaction.

Based on the results of the International research in Annals of Agricultural and Environmental Medicine (2018), the total of nursing staff in European countries including Poland and Lithuania suffered a decline, as they resigned and migrated to the developed world which further ensured their affairs. It is confirmed that several factors affecting the level of job satisfaction that is, the relationship between a poor coworker, a bad internal organization, a conflict with superiors, and a lack of understanding between nursing staff and superiors. Some research results conducted in Indonesia related to the work satisfaction of Noras and Sartika (2012) examining the job satisfaction of nurses categorized at low $22.5 \%$, research conducted by Ahsan and Adien (2015) at Mardi Waluyo Hospital in Blitar City also expressed the highest level of nursing work satisfaction is $27.9 \%$, in addition to the research conducted Hartono et al. (2018) expressed satisfaction nurse work at Paru Gunawan Hospital 57.9\%

Based on the descriptions on the background and the purpose of the review literature conducted by the research team the following review question was compiled "is the social support factor can affect the job satisfaction of nurses".

\section{Data sources and search}

The strategy was collecting journals as a literature study material using The PubMed Journal site, Willey Online Library and Google Scholar. The year the literary source is taken from 2015 until 2020. Search strategy with the keyword "social support OR nurse or Job satisfaction," and in Bahasa Indonesia "Dukungan Sosial dengan Kepuasan Kerja Perawat."

This is to make sure all the articles obtained are relevant and appropriate, then the full text is downloaded and saved.

\section{Screening}

After initial identification of titles and abstracts, PubMed obtained 418,738 articles, at Wiley Online Library acquired 34,229 whereas on Google Scholar acquired 4400 articles so total obtained 457,367 articles. The research was screened by title and abstract and then 752 articles were obtained. The researcher conducted a review with the full-text category so that 553 remaining articles were obtained and were examined independently, according to the inclusion criteria so that it became 199, articles were excluded because they did not meet the criteria with a total of 189 articles. The next article in the final stage was obtained 30 articles.

\section{Review Literature Method}

The process of selection had several stages: In the first stage, the results were screened for eligibility according to the inclusion and exclusion criteria. In the second stage, related to inclusion criteria, we selected peer-reviewed journal original research article published between 2015 and 2020, written in English and Croatian language. Literature review articles were excluded from the study. The process of selection and refining the studies is shown using PRISMA 2009 flow diagram. Excluded records were either considering methodologically of a less quality according to the subjective opinions of the reviewers. The main focus in this literature review is the Social Support Effect Nurse Job Satisfaction. To optimize this interpretation, we will first clarify the findings. The search flow is summarized in Table 1 image.

Table 1: Article search process

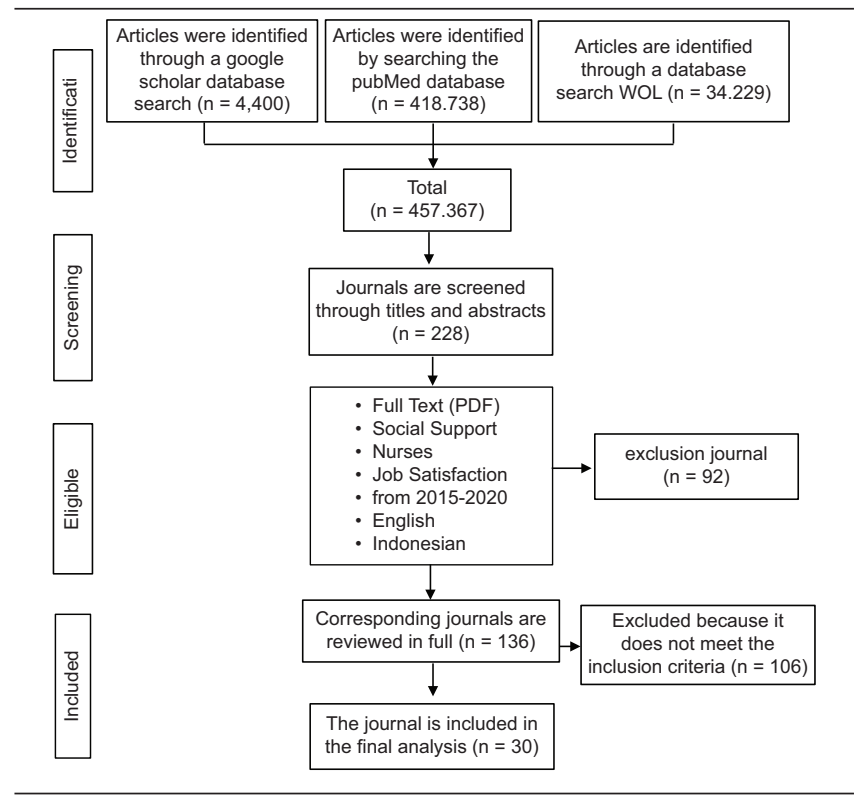

\section{Inclusion criteria and exclusion}

The following inclusion criteria are used in the review literature selection:

An original study (original journal or done by researchers)

1. Research on social support that affects nursing work satisfaction in hospitalization

2. Journal starting from 2015 to 2020

3. Available in Bahasa Indonesia and English

4. Full text.

The following exclusion criteria are used in the selection of this literary study:

1. Publications are not original such a letter editors, abstract only, and editorial.

Algorithm search (PRISMA, Moher et al., 2009) 
Table 2: Study characteristics

No. Author Title

1. Purdini et al. [3] The effect of job stress, work conflict, and social support on job satisfaction

2. Öksüz et al. [9] Resilience in nurse in terms of perceived social support, job satisfaction and certain variables

3. Orgambídez- Work Engagement, social support, and job Ramos and de satisfaction in Portuguese nursing staff: A Almeida [10] winning combination

4. Negussie and Kaur [11] and The efrect of job demand-control-social Support Model on Nurses' Job Satisfaction in Specialized Teaching Hospitals, Ethiopia

5. Han [12] Social The Moderating Effects of Social
Support between Emotional Labor and Job

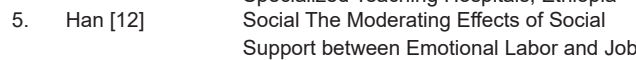
Satisfaction in Clinical Nurses The effect of social capital on job satisfaction and quality care of among hospital nurse in South Korea

7. Orgambídez- Social Support, Role Clarity and job Ramos and satisfaction: a successful combination for Borrego-Alés [14] nurses

8. Read and The influence of authentic leadership and Laschinger [15] empowerment on nurses' relational social capital, mental health and job satisfaction over the first year of practice

9. Feng et al. [16] The protective role of self-esteem, perceive social support, and job satisfaction against psychological distress among Chinese nurses

10. Jiang et al. [17] Organization-based self-esteem mediates the effects of social support and job satisfaction on intention to stay in nurses

11 Yang et al. [18] Relationship of work-family conflict, selfreported social support, and job satisfaction to burnout syndrome among medical workers in Southwest China: A crosssectional study

12 Lee [19] Effects of Nurses' Resilience, Job Satisfaction, and Social Support on Organizational Commitment

13 Labrague and de COVID-19 anxiety among front-line nurses: los Santos [20] Predictive role of organizational support, personal resilience, and social support Mediating effects of self-efficacy, coping burnout, and social support between job stress and mental health among young Chinese nurses

15 Polat et al. [22] The relationship between work-family conflict, organizational silence and socia support in nurses at a university hospital

16 RodríguezMonforte et al. [23] The influence of supervisory support, work effectiveness, work empowerment and stress study secondary to residents' responsive behaviors on job satisfaction of nursing staff: A multisite cross-sectional study

17 Türe and Akkoç The mediating role of social support in the [24] effect of perceived organizational support and psychological empowerment on career satisfaction in nurses

18 Polat and Terzi Relationships between perceived support [25] types and the job satisfaction levels of nurses

$\begin{array}{llll}\begin{array}{l}\text { Method study/ } \\ \text { design study }\end{array} & \text { Instrument } & \text { Sample } & \text { Result } \\ \begin{array}{l}\text { Explanatory } \\ \text { research }\end{array} & \begin{array}{l}\text { Questionnaire } \\ \text { survey }\end{array} & 70 \text { nurses } & \begin{array}{l}\text { The results of the study explained that working stress, } \\ \text { nurse work conflict, and the simultaneous social support } \\ \text { of nurses have a significant influence on nursing work } \\ \text { satisfaction }\end{array} \\ \text { Descriptive study } & \begin{array}{l}\text { Questionnaire } \\ \text { survey }\end{array} & 242 \text { nurses } & \begin{array}{l}\text { Among major findings, resilience, perception } \\ \text { of social support, and job satisfaction have positive } \\ \text { relationship results } \\ \text { Social support is a key element for promoting professional } \\ \text { activities that foster nurse staff job satisfaction levels }\end{array} \\ \text { Cross Sectional } & \begin{array}{l}\text { Questionnaire } \\ \text { survey }\end{array} & 215 \text { nurses } \\ \text { Cross Sectional } & \begin{array}{l}\text { Questionnaire } \\ \text { survey }\end{array} & 260 \text { nurses } & \begin{array}{l}\text { Job requests and social support are significantly related to } \\ \text { nursing work satisfaction }\end{array}\end{array}$

Research Naratif Post-test control 311 nurses variable

The results showed that it was important to develop social support by promoting and relieving stress programs for clinical nurses to improve job satisfaction

432 nurses Increasing social support with nurses' job satisfaction can be improved and result in better quality care for patients. Nursing management implications strategies to increase social support in nursing organizations are needed in increasing job satisfaction and the quality of care provided by nurses.

Cross sectional Questionnaire 191 nurses Performing role-playing functions as expected such as responsible and well-behaved, as well as the social support of employers and coworkers can give a higher working satisfaction effect

Longitudinal Questionnaire 191 nurses By creating a good working environment with structurally empowering, authentic leaders foster relational social capital (social relations between human beings) among new graduate nurses who produce good mental health and high job satisfaction

581 nurses Chinese nurses show very high prevalence of psychological disorders. Work satisfaction, self-esteem, and perceived social support are identified, as an important factor towards psychological distress

Cross sectional Questionnaire 791 nurses Self-esteem-based organization or OBSE which is survey abbreviated to OBSE is the value owned by an individual from the results of the study showed a positive effect that the three variables can support the desire or intention of staff nurses to not leave the job (turnover/resign)

Cross-sectional Questionnaires 1382 medical In conclusion, this study suggests that self-reported family study workers support and social support can influence levels of fatigue syndrome, and that job satisfaction is a much stronger influence on fatigue syndrome in medical workers in Southwest China

Cross-sectional Questionnaires 195 nurses To increase organizational commitment, it is necessary study to make programs such as systematic family support in increasing job satisfaction of nurses with their type of work and salary satisfaction

Cross-sectional Questionnaires 325 nurses Nurses who served in the frontline felt higher study organizational and social support tended to report lower anxiety related to COVID-19

A cross-sectional Questionnaires 1500 nurses Emotional exhaustion and social support may have significant mediating effects in the link between job stress and depression and anxiety. Strategies including deceasing emotional exhaustion, enhancing social support in work environment, and reducing job stressors would be useful to prevent depression and anxiety among young nurses

Cross-sectional Questionnaires 329 nurses Our study shows that social support can increase job satisfaction, welfare and family support should be

191 nursing $\begin{aligned} & \text { satisfaction, welfare and family support should be } \\ & \text { enhanced in hospital policy }\end{aligned}$ descriptive study nurses by the head nurse in nursing homes can reduce the effect of secondary stress on occupant responsive behavior on job satisfaction of nursing staff

442 nurses In this study, it was determined that social support has a partial mediating role in the influence of support to health workers such as nurses who are perceived to be career satisfaction, social support has a partial mediating role in the effect of psychological empowerment on career satisfaction of nurses in the hospital

Cross-sectional Questionnaires

655 nurses The results showed that social support, coworkers, and organizations are very important in increasing nurses' job satisfaction. Hospital managers expect health workers to carry out their duties in the best, most effective and efficient manner and be successful in their work to continue working in the hospital in achieving this, it is important that all employees, including nurses, are satisfied with their work 
Table 2: (Continued)

\begin{tabular}{lllllll}
\hline No. & Author & Title & $\begin{array}{l}\text { Method study/ } \\
\text { design study }\end{array}$ & Instrument & Sample & Result \\
\hline 19 & Hamaideh & Burnout, Social Support, and Job & Cross-sectional & Questionnaires & 181 nurses & The results of this study attracted attention and the
\end{tabular}

et al. [26] Satisfaction among Jordanian Mental Health design

Nurses

20 Mahmoudi et al. [27]
Effects of social support on nursing and midwifery
Systematic review Articles review method
18 articles

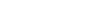

importance of improving the social and psychosocia work environment among nurses. To reduce fatigue while providing health services, administrators should also improve continuing education programs for nurses, especially programs related to stress management, coping skills, and personal skills and achievements, and updating of knowledge

Nurses are one of the most important occupations under the influence of the social support approach because of their direct communication with patients and clients at the puskesmas. Therefore, laying the groundwork for nurses' job satisfaction in creating appropriate health and treatment practices, delegating authority to nurses in several health center matters, creating health aspects, providing an approach to ensuring the physical and mental health of nurses, and helping to improve nurses in creating financial facilities, and well-being Permana [28] the contribution of social support on work satisfaction in nurses woman

22 Maria Helena Linking social support with job satisfaction: Almeida [29] The role of global empowerment in the workplace

23 Maria Helena Almeida [29]

The impact of workplace violence on job satisfaction, job burnout, and turnover intention: The mediating role of social support satisfaction, and psychological well-being among nurses in Spain Han et al. [12] The Moderating Effects of Social Support between Emotional Labor and Job Satisfaction in Clinical Nurses

26 Orgambídez Ramos and Social support and engagement as Borrego-Alés [14] staff

The role of supervisor emotional support on individual job satisfaction: A multileve analysis

Social support and factors associated practitioners

29 Azim and Islam [33]

Social Support, Religious Endorsement, and Career

Commitment: A Study on Saudi Nurses

30

$\begin{array}{ll}\text { Amarneh [34] } & \text { Social Support Behaviors and Work } \\ \text { Stressors among } \\ \text { Nurses: A Comparative Study between } \\ \text { Teaching and Non-Teaching Hospitals }\end{array}$
quantitative study
Quantitative

Cross-sectional

Questionnaires

Questionnaires

80 nurses

370 nurses

(1)

A cross sectional Questionnaires study

A cross sectional Questionnaires study

A cross-sectional Questionnaires study

A cross-sectional Questionnaires study

A cross-sectional Questionnaires study

cross $\square$ sectional Questionnaires survey study

Social support has a significant positive contribution to nurse job satisfaction, and that contribution is mediated by work-family conflict

Social support from superiors and colleagues as well as global empowerment seems to be two important determinants of nurses' job satisfaction in providing health care. Both types, such as social support, superiors, and colleagues, seem to affect job satisfaction either directly or indirectly through empowering nurses who work in hospitals

225 nurses The results show a high prevalence of workplace violence in Chinese tertiary hospitals, which should not be neglected. The effect of social support on behavior at work suggests that it has practical implications intervention to increase the stability of nurses who work in tertiary hospitals in China

2104 nurses The importance of intervention in providing social support at the individual level such as nurses and organizations to improve the quality of nursing in the working life of the hospital in providing health services

311 clinical The results of this study indicate that it is important nurses to develop social support for nurses in promoting and stress relief programs for clinical nurses to increase job satisfaction

215 nurses Interventions based on informal and formal support, training of supervisors in management and coaching skills, and greater social support from work and personal resources will increase the level of job satisfaction in nurses

323 nurses Contextual differences between groups have an impact on the form of job engagement-job satisfaction with the relationship between job engagement and job satisfaction is the relationship between individual and group level phenomena. Ways to increase supervisor emotional support include training supervisors in providing social support and improving communication between nurses and supervisors

429 nurses The self-efficacy of nursing practitioners in hospitals in Taiwan is not sufficient. Monthly salary and level of social support can contribute to job satisfaction. Thus, to improve Cross-sectional Questionnaires 146 nurses $\quad \begin{aligned} & \text { the self-efficacy and performance of nurse practitioners } \\ & \text { This study argues that social support and religious }\end{aligned}$ support are antecedents of career commitment in the context of the Saudi nursing profession. This suggests that social and religious support play an important role in determining career commitment among the sample studied

Comparative Questionnaires 463 nurses The findings suggest shift selection reduces shift work quantitative challenges for both new and experienced nurses, suggesting that workplace social support can influence nurses' job satisfaction. Senior nurses and management and at home play an important role in nurse coping

\section{Methodological characteristics}

Of the 30 articles reviewed, 23 articles using the design cross-sectional study [10], [11], [12], [13], [14], [16], [18], [23], [25], [26], [30], [31], [32], [33], [35], [36], [37], two articles using quantitative designs [28], [34], one article using explanatory research design 3, one article using descriptive study design [9], one article using Narrative Research design [12], one article using Longitudinal survey design [15], and one article using the Systematic review method design [27].

\section{Intervention method}

Out of the 30 articles, 28 used the questionnaire survey [3], [38], [10], [11], [39], [13], [14], [15], [16], [17], 
[18], [19], [20], [21], [22], [24], [25], [26], [28], [29], [30], [31], [32], [33], [34], [35], [36], [38]. One article using articles review [27] and one article using the post-test control variable design [12].

\section{Results}

The 30 articles that review (Table 2) in 19 articles expressed social support have a positive relationship results and have a significant influence on the work satisfaction of nurses [9], [37], [11], [13], [10], [3], [12], [15], [21], [22], [28], [14], [32], [34], four articles expressed social support and work satisfaction that have an effect directly affecting psychological distress [16], [17], [34], [20], one article [35] expressed social and job satisfaction significantly affects the intention of nurses to stay and not leave his job, two articles show that social support has a partial mediating role in the effect of psychological empowerment on career satisfaction of nurses in the hospital [24], [33], two articles show that nurses are one of the most important occupations under the influence of the social support approach because of their direct communication with patients and clients [27] and [31], one article shows that social support on behavior at work suggests practical implications intervention to increase the stability of nurses who work in tertiary hospitals in China [29], and one articles shows social support at the individual level such as nurses and organizations to improve the quality of nursing in the working life of the hospital in providing health services [30].

\section{Discussion}

In total, the literature of review obtained 30 articles and from 30 articles has significant results, among others:

Based on research results [3], social support can affect the level of nursing work satisfaction, the higher or increased social support then the satisfaction of nurse work will be improved. Job satisfaction is very important because it can determine the attitude of people at work and be a benchmark for the health and welfare of workers.

So that, it was mean that satisfaction can increase according to the perceived level of social support and with social support can improve the ability of nurses to overcome the stressor in the workplace. Emotional and instrumental support is a key element to promote the level of satisfaction of the workers, in addition to the informational support provided with friendly and fluent communication and sharing experience. Negative feelings experienced daily will make it possible to overcome stressful situations to control the mind and emotions in the workplace.

Social support contributes to the job satisfaction of nurses, nurses with high social support are protected from the negative effects of job demands on work satisfaction from nurses with low social support [11]. It is, therefore, important to develop interventions to promote social support and stress relief programs for nursing staff to improve job satisfaction.

Age and length of work became some of the determinants of social support levels gained, evidenced by the more support experienced by junior nurses than senior nurses. It resulted a lack of trust both internally and externally and a lack of solidarity. Therefore, it is hoped that hospital management should develop various strategies for the nurses to increase their trust and good solidarity.

Nurses receive support from coworkers and superiors he can execute their duties well and more competently so that it will be able to produce a good performance and will experience positive feelings that will have an impact on the high level of job satisfaction. Creating a good working environment with authentic leadership and structural empowerment also will be able to foster social relational capital among new graduate nurses, thus producing good mental health as well as high job satisfaction.

The psychological pressure felt is expected that nurse management must take steps to increase job satisfaction and social support so that it can help nurses mental health, then for nurses themselves must be able to take the initiative in doing social with other people or those closest to them so they can share their feelings so that they change support from those around them in fighting potential mental health problems.

Meanwhile, the results of the study [35] state that the effect is mediated by organization-based selfesteem with a significant level which has a direct effect on social support and job satisfaction. The existence of research is expected for hospital managers to appreciate and acknowledge the importance of nursing in the medical world to increase the intention of nurses to stay.

Based on the description, above article can be known that low social impact on nurses' satisfaction level, the lower the social support is obtained, the lower satisfaction that is felt. The result of job dissatisfaction felt by nurses often leads to boredom of workers which results in high levels of absenteeism, neglect, low achievement, slow work, low quality, service, and worker discipline problems. Dissatisfaction will result in decreased work performance resulting in changes to employment and declining work quality and impacting 
on professions and organizations [39]. Dissatisfaction will result in decreased work performance resulting in changes to work and decreased quality of work and an impact on the profession and organization. Low job satisfaction will make nursing services are low, and it is resulting in the increased ratio of death of the patient in the hospital after being treated in hospital.

\section{Conclusion}

All articles that have been discussed state that social support has a significant and positive effect on the job satisfaction of nurses. Social support and job satisfaction in nurses can also improve the welfare and health of nurses and enable nurses to adapt and survive difficult situations so they do not leave their jobs or leave work.

\section{Suggestion}

This research needs to be done in Indonesia if seen from the low level of work satisfaction felt by the nurse in Indonesia.

\section{Further researchers}

1. Data retrieval is not a questionnaire but through a direct interview with the respondent as well as the field observation directly

2. Longitudinal design for the long term to ensure the cause of the consequences of these two variables in the future.

\section{Hospitals in particular nursing management}

1. Have a role in policy-making in the workplace that will improve nursing work satisfaction as well as

2. Establishing open communication between workers' staff to create a good working relationship.

\section{References}

1. Zakaria A. Analisis Hubungan Harapan Karier Perawat Pelaksana Dengan Prestasi Kerja Di Rsud Swadana Jombang; 2010. p. 79-94.

2. Rahmadia F. Ecogen Pengaruh Lingkungan Kerja Fisik dan Dukungan Sosial Terhadap Stres Kerja Pada Perawat Rumah Sakit Islam (RSI) Ibnu Sina Payakumbuh Fitri Rahmadia, Rini Sarianti, Yuki Fitria Fakultas Ekonomi Universitas Negeri
Padang Email: fitrirahmadia21@gma; 2019. p. 2. https://doi. org/10.24036/jmpe.v2i2.6145

3. Purdini N, Musadieq M, Mayowan Y. The effect of work stress, work conflict and social support on job satisfaction (study on nurses at Handles Vereneging Hospital, Amsterdam (HVA) Toeloengredjo, Kediri Regency). J Adm Bisnis S1 Univ Brawijaya. 2016;38(2):131-40. https://doi.org/10.35308/jbkan. v3i2.1377

4. Mulyono $\mathrm{H}, \mathrm{Hamzah} \mathrm{AZ}$. Factors that influence the performance of nurses at level III hospitals 16.06.01 Ambon. J AKK. 2013;2(1):1-9.

5. Robbins SP. Management, Eleventh Canadian Edition. $11^{\text {th }}$ ed United Kingdom: Pearson; 2015.

6. Siagian SP. Manajemen Sumber Daya Manusia. Jakarta, Indonesia: Bumi Aksara; 2014.

7. Maria RA. Penerapan Sistem Informasi Manajemen Rumah Sakit Sebagai Salah Satu Strategi Peningkatan Mutu Layanan Rumah Sakit (Studi Pada Rumah Sakit Santo Borromeus Kota Bandung), Artikel; 2017. p. 1-13. https://doi.org/10.32502/jab. v5i1.2458

8. Shekelle PG. Nurse-patient ratios as a patient safety strategy. Ann Intern Med. 2013;158(5):404-9. https://doi. org/10.7326/0003-4819-158-5-201303051-00007

\section{PMid:23460097}

9. Öksüz E, Demiralp M, Mersin S, Tüzer H, Aksu M, Sarıkoc G. Resilience in nurses in terms of perceived social support, job satisfaction and certain variables. J Nurs Manag. 2019;27(2):423-32. https://doi.org/10.1111/jonm.12703 PMid:30209847

10. Orgambídez-Ramos A, de Almeida H. Work engagement, social support, and job satisfaction in Portuguese nursing staff: A winning combination. Appl Nurs Res. 2017;36:37-41. https:// doi.org/10.1016/j.apnr.2017.05.012

PMid:28720237

11. Negussie N, Kaur G. The effect of job demand-control-social support model on nurses' job satisfaction in specialized teaching hospitals, Ethiopia. Ethiop J Health Sci. 2016;26(4):311-320. https://doi.org/10.4314/ejhs.v26i4.3 PMid:27587929

12. Han HY, Lee JY, Jang I. The moderating effects of social support between emotional labor and job satisfaction in clinical nurses. Korean J Occup Health Nurs. 2015;24(4):331-9. https://doi. org/10.5807/kjohn.2015.24.4.331

13. Shin JI, Lee E. The effect of social capital on job satisfaction and quality of care among hospital nurses in South Korea. J Nurs Manag. 2016;24(7):934-42. https://doi.org/10.1111/jonm.12401 PMid:27197700

14. Orgambídez-Ramos A, Borrego-Alés Y. Apoyo social y engagement como antecedentes de la satisfacción laboral en personal de enfermería. Enferm Glob. 2017;16(4):208. https:// doi.org/10.6018/eglobal.16.4.260771

15. Read EA, Laschinger HK. The influence of authentic leadership and empowerment on nurses' relational social capital, mental health and job satisfaction over the first year of practice. J Adv Nurs. 2015;71(7):1611-23. https://doi.org/10.1111/jan.12625 PMid:25656433

16. Feng D, Su S, Wang L, Liu F. The protective role of selfesteem, perceived social support and job satisfaction against psychological distress among Chinese nurses. J Nurs Manag. 2018;26(4):366-72. https://doi.org/10.1111/jonm.12523 PMid:29624766

17. Jiang $\mathrm{Q}$, Song $\mathrm{S}$, Zhou J, Liu $\mathrm{Y}$, Chen $\mathrm{A}$, Bai $\mathrm{Y}$, et al. The prevalence, characteristics, and prevention status of skin injury caused by personal protective equipment among medical staff in fighting COVID-19: A multicenter, cross-sectional study. Adv 
Wound Care (New Rochelle). 2020;9(7):357-64. https://doi. org/10.1089/wound.2020.1212

PMid:32320359

18. Yang S, Liu D, Liu H, Zhang J, Duan Z. Relationship of workfamily conflict, self-reported social support and job satisfaction to burnout syndrome among medical workers in southwest China: A cross-sectional study. PLoS One. 2017;12(2):e0171679. https://doi.org/10.1371/journal.pone.0171679 PMid:28207821

19. Lee J. Effects of nurses' resilience, job satisfaction, and social support on organizational commitment. Korean J Health Serv Manag. 2018;12(1):57-67. https://doi.org/10.12811/ kshsm.2018.12.1.057

20. Labrague LJ, de los Santos JA. COVID-19 anxiety among frontline nurses: Predictive role of organisational support, personal resilience and social support. J Nurs Manag. 2020;28(7):165361. https://doi.org/10.1101/2020.07.16.20141069 PMid:32770780

21. Chen J, Li J, Cao B, Wang F, Luo L, Xu J. Mediating effects of self-efficacy, coping, burnout, and social support between job stress and mental health among young Chinese nurses. J Adv Nurs. 2020;76(1):163-73. https://doi.org/10.1111/jan.14208/v2/ response1

PMid:31566806

22. Polat S. Relationship between work-family conflict and organizational silence and social support in nurses at a University Hospital. J Psychiatr Nurs. 2018;9(3):195-204. https://doi.org/10.14744/phd.2018.38278

23. Rodríguez-Monforte M, Bethell J, Stewart S, Chu CH, EscrigPinol A, Gea-Sánchez M, et al. The influence of supervisory support, work effectiveness, work empowerment and stress secondary to residents' responsive behaviours on job satisfaction of nursing staff: A multisite cross-sectional study. J Nurs Manag. J Nurs Manag. 2021;29(3):497-507. https://doi. org/10.1111/jonm.13173

PMid:33030771

24. Türe $\mathrm{A}, \mathrm{Akkoç} \mathfrak{i}$. The mediating role of social support in the effect of perceived organizational support and psychological empowerment on career satisfaction in nurses. Perspect Psychiatr Care. 2020;56(4):985-93. https://doi.org/10.1111/ ppc. 12562

25. Polat Ş, Terzi B. Relationships between perceived support types and the job satisfaction levels of nurses. Perspect Psychiatr Care. 2020;57(3):1202-11. https://doi.org/10.1111/ppc.12675 PMid:33145771

26. Hamaideh SH. Burnout, social support, and job satisfaction among jordanian mental health nurses. Issues Ment Health Nurs. 2011;32(4):234-42. https://doi.org/10.3109/01612840.20 10.546494

PMid:21355758

27. Mahmoudi F, Hosseini SM, Joonbakhsh F, Ajoodanian N. Effects of social support on nursing and midwifery. J Crit Rev.
2020;7(12):1065-70.

28. Sirajuddin A, Permana MZ. The role of work-family conflict. J Psikol Insight. 2018;2(1):11-21. https://doi.org/10.17509/ insight.v2i1.11775

29. Maria Helena Almeida AOR and CMS. Linking Social Support with Job Satisfaction: The Role of Global Empowerment in the Workplace. London: Intech; 2017. p. 125-41.

30. Burke RJ, Moodie S, Dolan LF. Job demands, social support, work satisfaction and psychological well-being among nurses in Spain. ESADE Bus Sch Res Pap. 2020;9(5):7352-63. https:// doi.org/10.2139/ssrn.2117051

31. Pohl S, Galletta M. The role of supervisor emotional support on individual job satisfaction: A multilevel analysis. Appl Nurs Res. 2017;33:61-6. https://doi.org/10.1016/j.apnr.2016.10.004 PMid:28096025

32. Palareti G, Legnani C, Cosmi B, Antonucci E, Erba N, Poli D, et al. Comparison between different D-Dimer cutoff values to assess the individual risk of recurrent venous thromboembolism: Analysis of results obtained in the DULCIS study. Int J Lab Hematol. 2016;38(1):42-9. https://doi.org/10.1111/ijlh.12426 PMid:26362346

33. Azim MT, Islam MM. Social support, religious endorsement, and career commitment: A study on saudi nurses. Behav Sci (Basel). 2018;8(1):8. https://doi.org/10.3390/bs8010008

34. Amarneh BH. Social support behaviors and work stressors among nurses: A comparative study between teaching and nonteaching hospitals. Behav Sci (Basel). 2017;7(1):5. https://doi. org/10.3390/bs7010005

PMid:28146045

35. Chen MF, Ho CH, Lin CF, Chung MH, Chao WC, Chou HL, et al Organisation-based self-esteem mediates the effects of social support and job satisfaction on intention to stay in nurses. J Nurs Manag. 2016;24(1):88-96. https://doi.org/10.1111/jonm.12276 PMid:25612067

36. Duan X, Ni X, Shi L, Zhang L, Ye Y, Mu H, et al. The impact of workplace violence on job satisfaction, job burnout, and turnover intention: The mediating role of social support. Health Qual Life Outcomes. 2019;17(1):93. https://doi.org/10.1186/ s12955-019-1164-3

PMid:31146735

37. Orgambídez A, Almeida H. Social support, role clarity and job satisfaction: A successful combination for nurses. Int Nurs Rev. 2020;67(3):380-6. https://doi.org/10.1111/inr.12591 PMid:32436283

38. Park EH, Hong N, Jon DI, Hong HJ, Jung MH. Past suicidal ideation as an independent risk factor for suicide behaviours in patients with depression. Int J Psychiatry Clin Pract. 2017;21(1):24-8. https://doi.org/10.1080/13651501.2016.1249489 PMid:27854563

39. Edoho SA. Job satisfaction among nurses in public hospitals in calabar, cross river state Nigeria. Am J Nurs Sci. 2015;4(4):231. https://doi.org/10.11648/j.ajns.20150404.22 